\title{
CHARACTERISTICS OF INTERNET USE AS A MEANS OF PERCEIVED STRESS REDUCTION IN HEALTH CARE STUDENTS
}

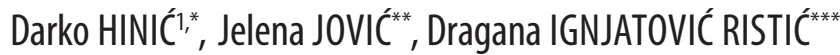 \\ "University of Kragujevac, Faculty of Sciences, Faculty of Philology and Arts \\ "Medical Faculty, University of Priština - Kosovska Mitrovica \\ "University of Kragujevac, Faculty of Medical Sciences
}

Previous studies suggest that people use media for instrumental needs, entertainment/leisure or for social gratification. The aim of this study is to identify specific characteristics of Internet use in health care students who use the Internet as a means of perceived stress reduction.

The sample included 231 students $(m=34 \% ; f=66 \%)$, aged $(M=22.44 ; S D=2.09)$, who were subsequently categorised into two groups according to whether they consciously use the Internet to alleviate the consequences of stressful experiences.

The individuals reporting the Internet as a means of perceived stress reduction spend considerably more time online than other Internet users. They also use contents related to entertainment, culture and sex more frequently, as well as social applications and networks. In comparison to others, these participants meet new people and potential partners more often via the Internet, spend more time on their friends' profiles, while using different entertainment applications, most commonly games.

The Internet may play a significant role in reducing negative reactions to stressful events; therefore, we may regard cyberspace as a fertile ground for educational, preventive and counselling services.

1 E-mail: dhinic@np.ac.rs 
Specijalna edukacija i rehabilitacija (Beograd), Vol. 15, br. 3. 305-327, 2016.

The main limitation to the current study is the sample (only health care students). Future studies should include assessment of perceived stress levels and their relation to study variables.

Key words: Internet use, health care students, mood management theory, stress, Uses and gratification theory

\section{INTRODUCTION}

There are numerous periods in life that represent a psychological transition from one established context into another, all of which are generally accompanied by a state of increased stress and decreased well-being due to the adjustment to norms, expectations and social networks (Mikal, Rice, Abeyta \& DeVilbiss, 2013). Such a period is time spent at university. Demanding academic requirements combined with psychosocial characteristics of this developmental stage can represent a significant source of stress for young people during their studies. Previous findings proved this to be particularly true for students of health professions (Baldassin, Alves, Andrade \& Martins, 2008; Kaya, Genç, Kaya \& Pehlívan, 2007).

Among other things, a high prevalence of depression and anxiety was reported in this population, with the average values of psychological distress being consistently higher than the ones in the general population of their peers (Dyrbye, Thomas \& Shanafelt, 2006; Knežević, Jović, Rančić \& Ignjatović-Ristić, 2012). In addition, the frequency of emotional exhaustion and burnout symptoms is higher in medical profession compared to the average value of other professions, and can be detected in 50 per cent of medical students, with a rising frequency rate during the course of studies (Backović \& Jevtić, 2012). There is further evidence of a positive correlation between the low level of emotional stability and oversensitivity to stress with the level of depression in the said population (Bunevicius, Katkute \& Bunevicius, 2008; Dahlin, Joneborg \& Runeson, 2005). What is also significant is that health care students use specific health services to a lesser extent in comparison to the general population, despite relatively easy access to it (Knežević 
Hinić, D., Jović, J., Ignjatović Ristić, D.: Characteristics of Internet use as a means of perceived stress reduction in health care students

et al., 2012). The reason why medical workers avoid seeking medical help is closely connected to the viewpoint reflecting the idea that mental problems are taken as a sign of weakness, which therefore could have further implications to career and professional development (Knežević et al., 2012).

Due to the reasons previously stated, it is critical to review forms of reaction and means of stress reduction that health care students employ. This paper is part of a broader study which has investigated stress reduction strategies in health care students2. After the initial results were delivered, it was noted that a growing number of university students resorted to Internet resources when looking for a solution to a problematic/stressful situation or simply spent time on the Internet when they wanted to turn their thoughts away from everyday problems (Jović, Hinić, Ignjatović-Ristić, Knežević \& Jović, 2012). It was at that point that we developed the idea to look at the reasons why university students are attracted to the Internet, and why they would rather decide on that stress management strategy than ask for help, for example, from their family and friends.

\section{Motivation for media use}

As stated before, although there are numerous stress reduction strategies, in this paper we will focus on the growing use of media for that purpose. The increasingly widespread availability and improved technologies provide a richer experience, greater comfort, expressivity and interactivity of online communication (Hinić, 2014). Nowadays, the vast majority of college students have been using online social-networking sites for a considerable time, and also for gratifications such as making new friends and keeping in touch with the old ones (Raacke \& Bonds-Raacke, 2008).

According to the Uses and gratifications theory (Ruggiero, 2000), people use media either for content gratifications

2 Some of the results were presented at the 3rd Congress of the Psychiatric Association for Eastern Europe and the Balkans, and 60th Annual Conference of the Serbian Psychological Association 
Specijalna edukacija i rehabilitacija (Beograd), Vol. 15, br. 3. 305-327, 2016.

(learning, entertainment), or for process gratifications (experience of the media usage, playing with the technology, browsing) (Stafford, Stafford \& Schkade, 2004). The third possible motivational line is social gratification arising from consumer use of the Internet as a social environment (Stafford et al., 2004). According to the mood management theory, media consumption can also temporarily reduce negative effects of stress by replacing anxious thoughts with other contents, as well as changing negative affective states to neutral or even positive states (Zillmann, 1988). Although the Internet has become an important source of information and a means of entertainment, there is a need for knowledge about how people use new information and communication technologies to manage stress.

Existing findings suggest that specific use of the Internet can become a positive strategy for reducing mental and physical aspects of stress and anxiety conditions (Chiauzzi, Brevard, Thurn, Decembrele \& Lord, 2008; Papacharissi \& Rubin, 2000). It is quite common for university students to meet friends through online social media and also to seek support in response to stress, particularly students studying away from home (Mikal \& Grace, 2011). Previous studies have shown a significant association of Internet health information use and perceived stress among college students (Fogel \& Israel, 2009). Online support groups, psychological assessment, counselling and Internet-based/ supported therapy may be a useful means of stress reduction (Barak \& Bloch, 2006). Online support groups enable people in distress to find others with similar needs and problems, to share feelings and information, provide advice, and develop a sense of a support, which is related to a participant's subsequent level of distress (Barak \& Dolev-Cohen, 2006). Online social networks cluster together different possibilities, and thus enable their users to derive simultaneously not only social support, advice, service information, but also entertainment and leisure contents (Hinić, 2014). This is the reason why it is essential to commence some research into the influence of this type of Internet interaction on the user's stress. 
Hinić, D., Jović, J., Ignjatović Ristić, D.: Characteristics of Internet use as a means of perceived stress reduction in health care students

This extensive study in particular had the aim to identify specific characteristics of Internet use in health care students who use the Internet as a means of stress reduction. The second part of the study had the goal to determine which specific characteristics of Internet social networks the participants use as stress reduction strategies, which is its most important contribution in comparison to other similar studies.

\section{METHOD}

Sample

The main criterion for the recruitment in this study was whether a student actively uses the Internet, and two groups of participants were formed accordingly: stress group (the participants who stated that they consciously use the Internet to alleviate the consequences of stressful experiences), and control group (the participants who claimed not to resort to the Internet when under stress, but rather use other strategies for stress reduction). The total of 231 health care students from the University of Kragujevac were recruited for this part of the study, $34 \%$ males and $66 \%$ females, with the age range of 19 $30(\mathrm{M}=22.44 ; \mathrm{SD}=2.09)$. There were no significant differences between the control and stress group with respect to the sociodemographic characteristics.

Table 1 - Sociodemographic characteristics of the sample

\begin{tabular}{lccc}
\hline & Total $(\mathrm{n}=231)$ & Stress group $(\mathrm{n}=88)$ & Control group $(\mathrm{n}=143)$ \\
\hline Sex & & & \\
\hline Male & $34.2 \%$ & $37.5 \%$ & $32.2 \%$ \\
\hline Female & $65.8 \%$ & $62.5 \%$ & $67.8 \%$ \\
\hline Year of study & & & \\
\hline I & $34.2 \%$ & $37.5 \%$ & $32.2 \%$ \\
\hline IV & $65.8 \%$ & $62.5 \%$ & $67.8 \%$ \\
\hline $\begin{array}{c}\text { Economic Status } \\
\text { Low }\end{array}$ & $4.8 \%$ & $5.4 \%$ & $4.2 \%$ \\
\hline Middle & $68.4 \%$ & $67.9 \%$ & $69.0 \%$ \\
\hline Higher & $26.8 \%$ & $26.7 \%$ & $26.9 \%$ \\
\hline Residence & & & \\
\hline At home & $25.4 \%$ & $29.0 \%$ & $21.9 \%$ \\
\hline Dormitory & $10.4 \%$ & $10.2 \%$ & $10.5 \%$ \\
\hline Rentals & $64.2 \%$ & $60.8 \%$ & $67.6 \%$ \\
\hline
\end{tabular}


Specijalna edukacija i rehabilitacija (Beograd), Vol. 15, br. 3. 305-327, 2016.

In this study we included university students attending first year of study, because during these early months students tackle with numerous challenges, such as developing a new social network, separation-individuation, keeping up with academic work in a new environment; hence this period is seen as a major transition of emerging adulthood (Mattanah et al., 2010). Fourth year of study was chosen since some findings suggest that medical students show an elevated level of stress at the transition from basic-to-clinical training and during the later years of studying (Helmers, Danoff, Steinert, Leyton \& Young, 1997).

The participation in the study was voluntary, anonymous, and the informed consent was provided.

\section{Procedure and instruments}

In the current study, we have included standard questions about sociodemographic features (sex, age, economic status, residence etc), and administered a questionnaire by which specific habits on the Internet, social networks and online applications use were analysed (Hinić, 2008). This questionnaire included items which were to determine the duration of the participants' Internet experience (expressed in years), average number of hours spent online weekly, average number of hours on social networks weekly, categories of online contents and activities. We examined how often the participants use the thirteen types of online contents (among others: sports, music, sex, arts, politics, computers), and ten specific online activities (email, chat, social networking, gaming, network search, download and others), which have proved to be the most frequent in previous studies (Hinić, 2008). The participants used a self-reported scale (a six-point Likert scale ranging from 0 - not at all to 5 - several hours every day) to rate the intensity of their average weekly online activities and online contents search. 
In the end, we also added several questions, in which the participants expanded on their reasons for using social networks and other applications, how often they displayed online behaviour different from their typical behaviour in reality, and whether they expressed disagreement and verbal aggression more easily through the Internet and social networks.

There are findings suggesting that adolescents who use the Internet excessively also consume alcohol and other psychoactive substances excessively (Ko et al., 2006). For this reason we have also included questions whether they use alcohol, sedatives and other psychoactive substances when under stress.

\section{RESULTS}

\section{Time spent online}

Individuals who report the Internet as a means of stress reduction spend considerably more time online than other Internet users $\left(F(229)=4.233, p<0.001\right.$, eta $\left.^{2}=0.073\right)$; the situation was similar as regards online social networks $(F(196)=3.469$, $p<0.001$, eta ${ }^{2}=0.031$ ). On average they actively spend seven hours a week online (five hours on social networks alone), whereas an average Internet user spends approximately five hours, out of which three are spent on social networks ${ }^{3}$.

3 What should be emphasised at this point is that the study was conducted two years ago, so the number of hours may no longer be as relevant as it was. The emphasis herein is placed on differences and not the mere number of hours. 
Specijalna edukacija i rehabilitacija (Beograd), Vol. 15, br. 3. 305-327, 2016.

Table 2 - Demographic differences in Internet use

\begin{tabular}{lcc}
\hline & $\begin{array}{c}\text { hours per } \\
\text { week online }\end{array}$ & $\begin{array}{c}\text { hours per week using social } \\
\text { networks }\end{array}$ \\
\hline $\begin{array}{l}\text { sex } \\
\text { stress group } \\
\text { sex } \\
\text { control group }\end{array}$ & $t(86)=0.581, p>0.10$ & $t(76)=1.199, p>0.10$ \\
\hline $\begin{array}{l}\text { years of study } \\
\text { stress group }\end{array}$ & $t(141)=-0.169, p>0.10$ & $t(118)=1.752, p>0.05$ \\
$\begin{array}{l}\text { years of study } \\
\text { control group }\end{array}$ & $t(86)=-0.887, p>0.10$ & $t(118)=0.666, p>0.10$ \\
\hline $\begin{array}{l}\text { econom.status } \\
\text { stress group } \\
\text { econom.status } \\
\text { control group }\end{array}$ & $F(2)=0.355, p>0.10$ & $F(2)=0.308, p>0.10$ \\
\hline $\begin{array}{l}\text { residence } \\
\text { stress group } \\
\text { residence } \\
\text { control group }\end{array}$ & $F(2)=3.910, p<0.05$ & $F(2)=1.979, p>0.10$ \\
\hline
\end{tabular}

Within the group who uses the Internet for stress reduction, students living in dormitories spend considerably more time on social networks than others. No differences were found according to the remaining demographic characteristics.

In the control group, males spend considerably more time on the Internet per week, and those with a low economic status significantly less.

\section{Online contents and activities}

The Internet contents subscale showed a satisfying internal consistency, both in the control and stress group $(\alpha=0.86$, and $\alpha=0.79)$. The same is applicable to the Internet activities subscale ( $\alpha=0.84$, and $\alpha=0.83$ ).

A statistically significant difference between these two groups was found with respect to using some of the specific online contents. 
Hinić, D., Jović, J., Ignjatović Ristić, D.: Characteristics of Internet use as a means of perceived stress reduction in health care students

Table 3 - Differences in the use of online content

\begin{tabular}{|c|c|c|c|c|c|c|c|c|}
\hline $\begin{array}{l}\text { online } \\
\text { content }\end{array}$ & & politics & sports & $\begin{array}{c}\text { computers \& } \\
\text { electronics }\end{array}$ & $\begin{array}{c}\text { arts \& } \\
\text { culture }\end{array}$ & education & $\begin{array}{l}\text { popular } \\
\text { culture }\end{array}$ & economy \\
\hline $\begin{array}{l}\text { control } \\
\text { group }\end{array}$ & $\begin{array}{l}M \\
(S D)\end{array}$ & $\begin{array}{c}0.44 \\
(0.92)\end{array}$ & $\begin{array}{c}1.49 \\
(1.72)\end{array}$ & $\begin{array}{c}0.78 \\
(1.30)\end{array}$ & $\begin{array}{c}1.66 \\
(1.51)\end{array}$ & $\begin{array}{c}2.80 \\
(1.54)\end{array}$ & $\begin{array}{c}1.92 \\
(1.67)\end{array}$ & $\begin{array}{l}0.33 \\
(0.77)\end{array}$ \\
\hline \multirow[t]{2}{*}{$\begin{array}{l}\text { stress } \\
\text { group }\end{array}$} & $\begin{array}{l}M \\
(S D)\end{array}$ & $\begin{array}{c}0.56 \\
(1.14)\end{array}$ & $\begin{array}{c}1.73 \\
(1.83)\end{array}$ & $\begin{array}{c}1.08 \\
(1.52) \\
\end{array}$ & $\begin{array}{c}1.95 \\
(1.49)\end{array}$ & $\begin{array}{c}3.03 \\
(1.43) \\
\end{array}$ & $\begin{array}{c}2.39 \\
(1.67)\end{array}$ & $\begin{array}{c}0.46 \\
(1.01)\end{array}$ \\
\hline & & $\begin{array}{c}229)=0.8 \\
p>0.10\end{array}$ & $\begin{array}{l}29)=0.9 \\
p>0.10\end{array}$ & $\begin{array}{c}\mathrm{t}(229)=1.580 \\
\mathrm{p}>0.10\end{array}$ & $\begin{array}{l}29)=1.46 \\
p>0.10\end{array}$ & $\begin{array}{c}t(229)=1.13 \\
p>0.10\end{array}$ & $\begin{array}{c}229)=2.04 \\
\mathbf{p}<0.05\end{array}$ & $\begin{array}{c}(229)=0.87 \\
p>0.10\end{array}$ \\
\hline
\end{tabular}

\begin{tabular}{|c|c|c|c|c|c|c|}
\hline $\begin{array}{l}\text { online } \\
\text { contents }\end{array}$ & $\begin{array}{c}\text { sexual } \\
\text { content }\end{array}$ & music & travelling & health & science & services \\
\hline $\begin{array}{ll}\text { control } & M \\
\text { group } & (S D)\end{array}$ & $\begin{array}{c}0.86 \\
(1.44)\end{array}$ & $\begin{array}{c}3.29 \\
(1.66)\end{array}$ & $\begin{array}{c}1.87 \\
(1,69)\end{array}$ & $\begin{array}{c}3.16 \\
(1.53)\end{array}$ & $\begin{array}{c}2.41 \\
(1.68)\end{array}$ & $\begin{array}{c}1.84 \\
(1.68)\end{array}$ \\
\hline $\begin{array}{ll}\text { stress } & M \\
\text { group } & (S D) \\
\end{array}$ & $\begin{array}{c}1.28 \\
(1.65)\end{array}$ & $\begin{array}{l}4.06 \\
(1.41)\end{array}$ & $\begin{array}{c}2.25 \\
(1.64) \\
\end{array}$ & $\begin{array}{c}3.36 \\
(1.34)\end{array}$ & $\begin{array}{c}2.35 \\
(1.78)\end{array}$ & $\begin{array}{c}1.94 \\
(1.65) \\
\end{array}$ \\
\hline & \multicolumn{6}{|c|}{$\mathrm{t}(166)=1.993, \mathrm{t}(206)=3.735, \mathrm{t}(229)=1.659, \mathrm{t}(229)=1.026, \mathrm{t}(22)=-0.259, \mathrm{t}(22)=0.460$} \\
\hline
\end{tabular}

The items on the scale were consequently factor-analysed, using the Principal Component Analysis (Varimax rotation with Kaiser Normalization), and three factors were extracted, which explained $58 \%$ of variance. Preliminary analyses showed a completely identical distribution of the items in both groups. Therefore, for easy reference, we have singled out the data applicable to the whole sample.

Table 4 - Factor loadings of the online content

\begin{tabular}{lccc}
\hline & Factor 1 & Factor 2 & Factor 3 \\
\hline popular culture & 0.760 & & \\
education & 0.728 & & \\
arts \& culture & 0.695 & & \\
music & 0.655 & & \\
travelling & 0.664 & & \\
science & 0.732 & & \\
health & 0.707 & & \\
services & 0.575 & & \\
politics & & 0.738 & \\
economy & & 0.709 & \\
computers \& electronics & & 0.731 & 0.850 \\
sexual content & & & 0.686 \\
sport & & & $8.43 \%$ \\
\hline Total variance $57.80 \%$ & $34.11 \%$ & $15.27 \%$ & \\
\hline
\end{tabular}

First factor is comprised of the information relevant to practical needs and entertainment activities. Second factor may be described as pertaining to business interests, and third specific interests predominant in male population. 
Specijalna edukacija i rehabilitacija (Beograd), Vol. 15, br. 3. 305-327, 2016.

A statistically significant difference between these two groups was found with respect to using some of the specific online activities.

Table 5 - Differences in online activities

\begin{tabular}{|c|c|c|c|c|c|c|}
\hline $\begin{array}{l}\text { online } \\
\text { activities }\end{array}$ & & email & chat & forums & $\begin{array}{c}\text { soc. } \\
\text { networks }\end{array}$ & surfing \\
\hline $\begin{array}{l}\text { control } \\
\text { group }\end{array}$ & $\begin{array}{l}M \\
(S D)\end{array}$ & $\begin{array}{c}1.23 \\
(1.17)\end{array}$ & $\begin{array}{c}1.69 \\
(1.56)\end{array}$ & $\begin{array}{c}0.59 \\
(1.11)\end{array}$ & $\begin{array}{c}1.97 \\
(1.73)\end{array}$ & $\begin{array}{c}1.82 \\
(1.60)\end{array}$ \\
\hline \multirow[t]{2}{*}{$\begin{array}{l}\text { stress } \\
\text { group }\end{array}$} & $\begin{array}{l}M \\
(S D)\end{array}$ & $\begin{array}{c}1.43 \\
(1.48)\end{array}$ & $\begin{array}{c}2.62 \\
(1.92)\end{array}$ & $\begin{array}{c}1.06 \\
(1.46)\end{array}$ & $\begin{array}{c}2.55 \\
(1.64)\end{array}$ & $\begin{array}{c}2.18 \\
(1.70)\end{array}$ \\
\hline & & $\begin{array}{l}52)=1.08 \\
p>0.10\end{array}$ & $\begin{array}{c}(156)=3.873, \\
\mathbf{p}<0.001\end{array}$ & $\begin{array}{c}(149)=2.595 \\
\mathbf{p}<\mathbf{0 . 0 1}\end{array}$ & $\begin{array}{c}(229)=2.522 \\
\mathbf{p}<\mathbf{0 . 0 5}\end{array}$ & $\begin{array}{c}t(229)=1.636 \\
p>0.10\end{array}$ \\
\hline $\begin{array}{l}\text { online } \\
\text { activities }\end{array}$ & & games & download & $\begin{array}{l}\text { listening to } \\
\text { music }\end{array}$ & news & search \\
\hline $\begin{array}{l}\text { control } \\
\text { group }\end{array}$ & $\begin{array}{l}M \\
(S D)\end{array}$ & $\begin{array}{c}1.68 \\
(1.61) \\
\end{array}$ & $\begin{array}{c}2.75 \\
(1.60)\end{array}$ & $\begin{array}{c}2.95 \\
(1.45)\end{array}$ & $\begin{array}{c}0.83 \\
(1.42)\end{array}$ & $\begin{array}{c}2.94 \\
(1.40)\end{array}$ \\
\hline \multirow[t]{2}{*}{$\begin{array}{l}\text { stress } \\
\text { group }\end{array}$} & $\begin{array}{l}M \\
(S D)\end{array}$ & $\begin{array}{c}2.42 \\
(1.69) \\
\end{array}$ & $\begin{array}{c}3.07 \\
(1.81) \\
\end{array}$ & $\begin{array}{c}3.05 \\
(1.54) \\
\end{array}$ & $\begin{array}{c}1.01 \\
(1.61) \\
\end{array}$ & $\begin{array}{c}3.31 \\
(1.56) \\
\end{array}$ \\
\hline & & $\begin{array}{l}29)=3.3 \\
\mathbf{p}<0.01\end{array}$ & $\begin{array}{c}t(229)=1.40 \\
\quad p>0.10\end{array}$ & $\begin{array}{c}t(229)=0.470 \\
p>0.10\end{array}$ & $\begin{array}{c}t(229)=0.92 \\
p>0.10\end{array}$ & $\begin{aligned} 1, t(229) & =1.830 \\
p> & 0.05\end{aligned}$ \\
\hline
\end{tabular}

The items on this scale were also factor-analysed, using the Principal Component Analysis (Varimax rotation with Kaiser Normalization). In contrast to the previous analysis presented above, the distribution of the factors differed in these two groups.

Table 6 - Factor loadings of the online activities

\begin{tabular}{|c|c|c|c|c|c|c|}
\hline $\begin{array}{l}\text { stress } \\
\text { group }\end{array}$ & instrumen. & social & entertain. & $\begin{array}{l}\text { control } \\
\text { group }\end{array}$ & $\begin{array}{l}\text { instrum. \& } \\
\text { entertain. }\end{array}$ & social \\
\hline \multirow{7}{*}{$\begin{array}{l}\text { news } \\
\text { download } \\
\text { search } \\
\text { surfing } \\
\text { e-mail } \\
\text { social } \\
\text { networks } \\
\text { chat }\end{array}$} & \multirow{10}{*}{$\begin{array}{l}0.788 \\
0.756 \\
0.725 \\
0.561\end{array}$} & \multirow{10}{*}{$\begin{array}{c}0.0737 \\
0.657 \\
0.629\end{array}$} & & \multirow{10}{*}{$\begin{array}{l}\text { news } \\
\text { surf } \\
\text { search } \\
\text { download } \\
\text { games } \\
\text { listening to } \\
\text { music } \\
\text { chat } \\
\text { social } \\
\text { networks } \\
\text { forums } \\
\text { e-mail }\end{array}$} & 0.786 & \\
\hline & & & & & 0.779 & \\
\hline & & & & & 0.754 & \\
\hline & & & & & 0.657 & \\
\hline & & & & & 0.524 & \\
\hline & & & & & 0.463 & 0.539 \\
\hline & & & & & & 0.762 \\
\hline forums & & & 0.730 & & & 0.714 \\
\hline \multirow{2}{*}{$\begin{array}{l}\text { games } \\
\text { listening to } \\
\text { music }\end{array}$} & & & 0.780 & & & 0.667 \\
\hline & & & 0.530 & & & 0.662 \\
\hline $\begin{array}{l}\text { Total var. } \\
63.68 \%\end{array}$ & $30.78 \%$ & $17.30 \%$ & $15.60 \%$ & $\begin{array}{l}\text { Total var. } \\
53.29 \%\end{array}$ & $30.74 \%$ & $22.55 \%$ \\
\hline
\end{tabular}


Hinić, D., Jović, J., Ignjatović Ristić, D.: Characteristics of Internet use as a means of perceived stress reduction in health care students

Whereas the activities directed at a practical gain and fun were divided in the stress group, in the control group these two dimensions merged into one. We did not, however, analyse differences in scores in extracted factors between the two groups because we believe it is more insightful to analyse differences in individual online contents and activities since specific differences may be lost by grouping some of the contents/activities.

\section{The reasons for using social networks and applications}

With regard to social relations, an important finding is that the individuals who use the Internet for stress reduction go out and make friends (47\%) considerably less $\left(\chi^{2}(1)=7.331\right.$, $p<0.01$, Phi $=0.187)$ when under stress, then the other group (60\%). Nevertheless, the difference was within a low impact according to Phi values.

Although the majority use chat and social networks primarily for communicating with friends and relatives, the participants who use the Internet for stress reduction also use the Internet more often for meeting new people (40.9\%), and chat for fulfilling spare time and avoiding boredom (66,7\%) $\left(\chi^{2}(3)=29.681, p<0.001\right)$. Within the said group (Table 7), there is a considerable number of individuals who have a profile on one or more social networks $\left(\chi^{2}(1)=7.223, p<0.01\right.$, Phi $\left.=0.180\right)$, and spend considerably more time on their friends' profiles $(t(194)=2.531, p>0.05)$ and those of their friends' friends $(t(197)=2.104, p>0.05)$, as well as various associations and groups $(t(193)=2.483, p>0.05)$. They also use social networks entertainment applications, such as games, more frequently $\left(\chi^{2}(1)=6.528, p<0.05\right)$. 
Specijalna edukacija i rehabilitacija (Beograd), Vol. 15, br. 3. 305-327, 2016.

Table 7 - Differences in social network behaviour

\begin{tabular}{lcccc}
\hline & $\begin{array}{c}\text { social network social network } \\
\text { profiles }\end{array}$ & $\begin{array}{c}\text { express } \\
\text { games }\end{array}$ & $\begin{array}{c}\text { verbal } \\
\text { disagreement } \\
\text { aggression }\end{array}$ \\
\hline stress group & $92.0 \%$ & $18.2 \%$ & $17.0 \%$ & $32.1 \%$ \\
\hline control group & $80.0 \%$ & $12.0 \%$ & $10.8 \%$ & $20.3 \%$ \\
\hline
\end{tabular}

Interestingly, there were no differences found in the participants' answers to the question whether they express disagreement more easily through social networks $\left(\chi^{2}(2)=4.507\right.$, $p>0.10)$ or verbal aggression $\left(\chi^{2}(2)=2.675, p>0.10\right)$, nor how often they display behaviour different from their typical behaviour in reality $(t(229)=1.437, p>0.01)$.

There was not a sufficient number of the participants who stated to use sedatives and other similar psychoactive substances when under stress so as to perform proper analyses. However, the analysis showed that the participants using alcohol as a means of stress reduction use the Internet significantly more for the same purpose $(t(229)=3.649, p<0.001)$.

\section{DISCUSSION}

Previous research has extracted three dimensions of Internet use, predominantly common among all Internet users regardless of intensity of use (Hinić, 2008). The first dimension refers to using the Internet with an aim to access up-to-date and useful information (with regard to school and work for instance), and it is based on instrumental needs. The second dimension is conceptually broad and entails a need for information in relation to entertainment/leisure, hobbies, sports, sexual contents, music, popular culture and art. The third dimension is founded on social motives, it encompasses various forms of social interaction, such as emailing, chatting, forums, and social networks.

We obtained a similar structure in our study, especially in the stress group, while in the control group some categories of online activities were clustered. In accordance with our factor analysis results concerning online activities (Table 6), 
Hinić, D., Jović, J., Ignjatović Ristić, D.: Characteristics of Internet use as a means of perceived stress reduction in health care students

it becomes apparent that students who use the Internet as a means of stress reduction use the Internet for emotional (e.g. entertainment and leisure), instrumental (e.g. gathering of useful information for practical purposes), and social support (social interaction). Contemporaneous studies report that entertainment, surfing the Internet and playing games are the contents and activities important for reducing stress levels (Leung, 2007). Despite the fact that different studies report different forms of social support, the most frequent online support features were desire to acquire a sense of community, need for information, and ability to "co-cope" with others and sensitive issues (Mikal et al., 2013).

As regards concrete contents, the participants belonging to the stress group are increasingly consuming electronic contents related to popular culture, sex and music. They also spend considerably more time on social applications, such as chats, forums, discussion groups or some social networks, most frequently Facebook, where they frequently have more than one profile. Although there are three clearly extracted dimensions of Internet use, the stress group differs from nonstress group mostly regarding categories which pertain to emotional and social dimensions.

This is in line with the existing results which indicate that less commonly reported gratifications include learning about events, sharing information, academic purposes (Raacke \& Bonds-Raacke, 2008). Our findings suggest that the Internet may be rather used as a means for achieving emotion-focused and avoidance strategy than problem-focused stress coping strategy.

\section{Social and emotional gratification of media use}

Mood management is the most prominently cited emotional gratification of media use (Hinić, 2014). People will seek media as regulation for or distraction from their bad mood. An overview of research on emotional gratifications of 
media use shows that emotions can be gratifying on different levels, ranging from simple hedonistic gratifications to more complex gratifications, such as the satisfaction of social and cognitive needs (Bartsch \& Viehoff, 2010). For example, television viewers under stress more often consume contents with elements of entertainment, humour and games (Zillmann \& Bryant, 1985), which has been confirmed by our participants who more often use the Internet to avoid monotony or distract their thoughts from negative contents of reality.

The Internet has become a widely used resource for obtaining social support and relations. The most important Internet activity serving the function of stress reduction in adolescents is chatting (social interaction), considerably more than online games, which were expected to have a similar role (Leung, 2007). According to the social compensation theory (Jochen, Valkenburg \& Schouten, 2005), the mentioned functions are particularly important to persons who may thus reduce the consequences of insufficient social support, which has been confirmed in several studies of Internet behaviour (Bodroža, Jovanović \& Popov, 2008; Leung, 2002). A low level of social support increases a risk of depression for more than ten times in students of medicine (Jeong et al., 2010), especially in students living away from their parents (Roh, Jeon, Kim, Han \& Hahm, 2010). Avoidance of these very consequences may be the reason why the students living away from home in our study (in the first place in dormitories) use social networks more.

Very popular gratifications for having social network accounts to keep in touch with old friends, with current friends and finally to make new friends, indicate that users meet their social needs through virtual communities and online services (Raacke \& Bonds-Raacke, 2008). Although the Internet is still predominantly used as a means of communication with family and friends, the students who use the Internet as a means of stress reduction use broader aspects of this medium, mainly for widening their social support networks (meeting new people or potential partners). 
Lonely and socially anxious adolescents more often communicate through the Internet with people they do not know from the real world (Gross, Juvonen \& Gable, 2002), whereas individuals who use avoiding strategies for stress reactions in reality consume entertaining contents on the Internet more (Seepersad, 2004). Let us remind ourselves that in our study the individuals who used the Internet for stress reduction reported that they go out and make friends considerably less when under stress than persons who do not use the Internet for stress reduction. The fact that Internet users can anonymously or even under a different identity discuss the very stressogenic situations which they are exposed to, by visiting forums, chat rooms or online communities, and thus significantly reduce internal tension (Amstadter, BromanFulks, Zinzow, Ruggiero \& Cercone, 2009; Eichhorn, 2008).

A variety of research programmes suggest that many individuals find it difficult to obtain proper support from friends and family (Wright, 2010). Individuals may feel more comfortable to share with individuals with whom they do not share overlapping relationships, but similar concerns, interests, and similar problems (Wright, 2010). People that we share weak ties with (somewhat limited social interaction with no strong emotional involvement) are also in a better position to provide objective, disimpassioned feedback on our problems. Pieces of advice that may be particularly useful can be taken from those individuals who have already gone through similar stressful situations.

These findings are somewhat in contrast to our participants' responses who stated that electronic communication did not encourage them to express either their disagreement or verbal aggression through social networks more willingly or behaviour different from the one in reality. However, we must be cautious with regard to these findings due to the methodological characteristics of our research (self-reported data) and potentially socially desirable answers. 
Specijalna edukacija i rehabilitacija (Beograd), Vol. 15, br. 3. 305-327, 2016.

\section{CONCLUSION}

Stress is increasingly cited as a precondition for the development of a number of psychological problems, from emotional exhaustion, anxiety, excessive food consumption, problematic drinking, drug abuse, professional burnout to depressive disorders (Li, Wang \& Wang, 2009; Chiauzzi et al., 2008; Dyrbye et al., 2006). Undoubtedly, there are studies suggesting that the Internet can be a source of stress. Nonetheless, it is apparent that its role could be just the opposite. Using the Internet may even have a positive effect on depressive symptomatology or symptoms, such as impulse control disorders, feelings of isolation, stress, anxiety, or forms of addictions (Mihajlović et al., 2008).

A number of studies that dealt with Internet use in promoting mental health have showed encouraging preliminary results. The work of various support groups whose activities are implemented throughout the Internet has proved to be successful in the recovery of patients suffering from post-traumatic syndrome (Amstadter et al., 2009), Alzheimer's dementia (Brennan, Moore, \& Smyth, 1995), eating disorders (Eichhorn, 2008), and depression (Thomas, Lisa \& Daniel, 2002). This role of the Internet should be exploited more because cyberspace may be regarded as a fertile ground for educational, preventive and counselling services.

Since there is a delicate balance between the agents that trigger stress reaction and those that alleviate it, the contents that entertain and relax Internet users may be significant for stress reduction, but they may also represent a potential risk for the development of new sources of stress. It is evident that the participants perceive the Internet as a place where they can obtain some credible information, a fun place where they feel less lonely, a place through which they can receive social support, a place that is always available (Leung, 2007). Nevertheless, some warning findings imply that users' profiles of our sample are similar to those of individuals with Internet 
Hinić, D., Jović, J., Ignjatović Ristić, D.: Characteristics of Internet use as a means of perceived stress reduction in health care students

use disorder symptoms (Hinić, 2008; Hinić, 2011). Studies have shown social anxiety to be significantly associated with excessive use of virtual social communities, especially the one with a compensation function (Bodroža et al., 2008). As with other defence mechanisms against unwanted contents and thoughts, if the abovementioned strategies do not develop in realistic and practical actions with an aim to overcome initial stress events, these behaviours may be transformed into an additional source of stress (Hinić, 2014).

The results of research on college students support the thesis that stressful life events contribute to Internet use disorder indirectly through avoidant coping style (especially self-blame, fantasy, withdrawal, rationalisation), and lower scores on the problem-seeking subscale ( $\mathrm{Li}$ et al., 2009). A similar study on adolescent population has shown that the relationship between stressful life events and Internet use disorder also varied with adolescents' temperament (effortful control and sensation seeking), and adolescents' maladaptive, unrealistic or all-or-nothing cognitions about Internet use ( $\mathrm{Li}$, Zhang, Li, Zhen \& Wang, 2010).

Our results are a good starting point for further exploration of these issues, particularly in the promotion and maintenance of mental health of the student population.

\section{Limitations and suggestions for future research}

The main limitation to the current study is sampling. The sample was not nationally representative (it included only health care students from one university), which can limit generalisation to other student subpopulations.

We did not formally assess stress levels because this will be the task of a future study which will measure stress levels of individuals who use or do not use the Internet for stress reduction. In future studies it would be useful to distinguish 
Specijalna edukacija i rehabilitacija (Beograd), Vol. 15, br. 3. 305-327, 2016.

between chronic and acute stressors, since social coping may differ based on the nature of the stressor. Similarly, although it seems that our evidence suggests online stress-reduction through the emotion-focused and avoidance strategies, it would be also useful to further investigate the use of these and other strategies (e.g. problem-focused strategy) in Internet and social network users, employing an instrument which directly measures these strategies.

Finally, on the basis of previous findings, we could expand the existing claims about the causes of Internet use and present a hypothetical model to be verified in future studies, in which confirmatory factor analysis should substantiate the existence of the proposed latent dimensions of Internet use in individuals who perform stress reduction in this way. In addition to the instrumental needs (e.g. search for information), the second dimension comprises the need for fun and emotional relief, while the social dimension apparently includes the maintenance of existing relationships (with friends and family) and the need to build up new relationships and expand the existing social support network.

\section{REFERENCES}

1. Amstadter, A.B., Broman-Fulks, J., Zinzow, H., Ruggiero, K. J., \& Cercone, J. (2009). Internet based interventions for traumatic stress-related mental health problems: A review and suggestion for future research. Clinical Psychology Review, 29(5), 410-420.

2. Backović, D., \& Jevtić, M. (2012). Burnout sindrom kao problem mentalnog zdravlja studenata medicine. Medical Review, 65(3-4), 129-132.

3. Baldassin, S., Alves, T. C. T. F., Andrade, A. G., \& Martins, L. A. N. (2008). The characteristics of depressive symptoms in medical students during medical education and training: a cross-sectional study. BMC Medical Education, 8, 60. 
Hinić, D., Jović, J., Ignjatović Ristić, D.: Characteristics of Internet use as a means of perceived stress reduction in health care students

4. Barak, A., \& Bloch, N. (2006). Factors related to perceived helpfulness in supporting highly distressed individuals through an online support chat. CyberPsychology \& Behavior, 9, 60-68.

5. Barak, A., \& Dolev-Cohen, M. (2006). Does activity level in online support groups for distressed adolescents determine emotional relief. Counselling and Psychotherapy Research, 6, 120-124.

6. Bartsch, A., \& Viehoff, R. (2010). The use of media entertainment and emotional gratification. Procedia - Social and Behavioral Sciences, 5, 2247-2255.

7. Bodroža, B., Jovanović, S., \& Popov, B. (2008). Latent structure of behaviour on social networking sites and its relation to social anxiety. Primenjena psihologija, 1(1-2), 19-35.

8. Brennan, P. F., Moore, S. M., \& Smyth, K. (1995). The effects of a special computer network on caregivers of persons with Alzheimer's disease. Nursing Research, 44(3), 166-172.

9. Bunevicius, A., Katkute, A., \& Bunevicius, R. (2008). Symptoms of anxiety and depression in medical students and in humanities students: relationship with big-five personality dimensions and vulnerability to stress. International Journal of Social Psychiatry, 54(6), 494-501.

10. Chiauzzi, E., Brevard, J., Thurn, C., Decembrele, S., \& Lord, S. (2008). My Student Body-Stress: An online stress management intervention for college students. Journal of Health Communication, $13,555-572$.

11. Dahlin, M., Joneborg, N., \& Runeson, B. (2005). Stress and depression among medical students: a cross-sectional study. Medical Education, 39(6), 594-604.

12. Dyrbye, L. N., Thomas, M. R., \& Shanafelt, T. D. (2006). Systematic review of depression, anxiety, and other indicators of psychological distress among U.S. and Canadian medical students. Academic Medicine, 81(4), 354-373.

13. Eichhorn, K. C. (2008). Soliciting and providing social support over the Internet: An investigation of online eating disorder support groups. Journal of Computer-Mediated Communication, 14(1), 67-78. 
Specijalna edukacija i rehabilitacija (Beograd), Vol. 15, br. 3. 305-327, 2016.

14. Fogel, J., \& Israel, S. (2009). Consumer attitudes regarding internet health information and communication: Gender, locus of control, and stress implications. International Journal of Clinical and Health Psychology, 9(2), 275-286.

15. Gross, E., Juvonen, J., \& Gable, S. (2002). Internet use and wellbeing in adolescence. Journal of Social Issues, 58, 75-90.

16. Helmers, K. F., Danoff, D., Steinert, Y., Leyton, M., \& Young, S. N. (1997). Stress and depressed mood in medical students, law students, and graduate students at McGill University. Academic Medicine, 72(8), 708-714.

17. Hinić, D. (2008). User profiles of Internet addicts in Serbia. Psychology, 41(4), 435-453.

18. Hinić, D. (2011). Problems with 'Internet Addiction' Diagnosis and Classification. Psychiatria Danubina, 23(2), 145-151.

19. Hinić, D. (2014). Internet komunikacije i poremećaj upotrebe interneta [Internet communication and Internet use disorder]. Kragujevac: Faculty of medical sciences.

20. Jeong, Y., Kim, J. Y., Ryu, J. S., Lee, K. E., Ha, E. H., \& Park, H. (2010). The Associations between social support, health-related behaviors, socioeconomic status and depression in medical students. Epidemiology and Health, 32, http://dx.doi.org/10.4178/ epih/e2010009.

21. Jochen, P., Valkenburg, P. M., \& Schouten, A. P. (2005). Developing a model of adolescent friendship formation on the Internet. CyberPsychology and Behavior, 8(5), 423-430.

22. Jović, J., Hinić, D., Ignjatović-Ristić, D., Knežević, M., \& Jović, S. (2012). Internet as a mean of stress reduction? III Congress of the Psychiatric Association for Eastern Europe and the Balkans, Belgrade.

23. Kaya, M., Genç, M., Kaya, B., \& Pehlivan, E. (2007). Prevalence of depressive symptoms, ways of coping, and related factors among medical school and health services higher education students. Turkish Journal of Psychiatry, 18, 137-146.

24. Knežević, M. Ž., Jović, J. J., Rančić, N. K., \& Ignjatović-Ristić, D. (2012). Depresivnost kod studenata medicine. Medicinski časopis, 46(1), 41-46. 
Hinić, D., Jović, J., Ignjatović Ristić, D.: Characteristics of Internet use as a means of perceived stress reduction in health care students

25. Ko, C. H., Yen, J. Y., Chen, C. C., Chen, S. H., Wu, K., \& Yen, C. F. (2006). Tridimensional personality of adolescents with internet addiction and substance use experience. Canadian Journal of Psychiatry, 51(14), 887-894.

26. Leung, L. (2002). Loneliness, self-disclosure, and ICQ. CyberPsychology and Behavior, 5(3), 241-255.

27. Leung, L. (2007). Stressful life events, motives for internet use, and social support among digital kids. CyberPsychology and Behavior, 10(2), 204-214.

28. Li, H., Wang, J., \& Wang, L. (2009). A survey on the generalized problematic Internet use in Chinese college students and its relations to stressful life events and coping style. International Journal of Mental Health and Addiction, 7(2), 333-346.

29. Li, D., Zhang, W., Li, X., Zhen, S., \& Wang, Y. (2010). Stressful life events and problematic Internet use by adolescent females and males: A mediated moderation model. Computers in Human Behavior, 26(5), 1199-1207.

30. Mattanah, J. F., Ayers, J. F., Brand, B. L., Brooks, L. J., Quimby, J. L., \& McNary, S.W. (2010). A social support intervention to ease the college transition: Exploring main effects and moderators. Journal of College Student Development, 51(1), 93-108.

31. Mihajlović, G., Hinić, D., Damjanović, A., Gajić, T., \& ĐukićDejanović, S. (2008). Excessive internet use and depressive disorders. Psychiatria Danubina, 20, 5-14.

32. Mikal, J., \& Grace, K. (2011). Against abstinence only education abroad: Viewing Internet use during study abroad as a possible experience enhancement. Journal of Studies in International Education, 16(3), 287-306.

33. Mikal, J. P., Rice, R. E., Abeyta, A., \& DeVilbiss, J. (2013). Transition, stress and computer-mediated social support. Computers in Human Behavior, 29, A40-A53.

34. Papacharissi, Z., \& Rubin, A. M. (2000). Predictors of Internet use. Journal of Broadcasting \& Electronic Media, 44(2), 175-196.

35. Raacke, J., \& Bonds-Raacke, J. (2008). MySpace and Facebook: Applying the Uses and gratifications theory to exploring friendnetworking sites. Cyberpsychology \& Behavior, 11(2), 169-174. 
Specijalna edukacija i rehabilitacija (Beograd), Vol. 15, br. 3. 305-327, 2016.

36. Roh, M. S., Jeon, H. J., Kim, H., Han, S. K., \& Hahm, B. J. (2010). The prevalence and impact of depression among medical students: a nationwide cross-sectional study in South Korea. Academic Medicine, 85, 1384-1390.

37. Ruggiero, T. E. (2000). Uses and gratifications theory in the 21st Century. Mass Communication and Society, 3(1), 3-37.

38. Seepersad, S. (2004). Coping with loneliness: Adolescent online and offline behavior. CyberPsychology and Behavior, 7(1), 35-39.

39. Stafford, T. F., Stafford, M. R., \& Schkade, L. L. (2004). Determining uses and gratifications for the Internet. Decision Sciences, 35(2), 259-288.

40. Thomas, K., Lisa, C., \& Daniel, F. (2002). Internet support groups for depression: A 1-year prospective cohort study. American Journal of Psychiatry, 159(12), 2062-2068.

41. Wright, K. B. (2010). Weak-tie support network preference and perceived life stress among participants in health-related, computer-mediated support groups. Journal of ComputerMediated Communication, 15, 606-624.

42. Zillmann, D. (1988). Mood management through communication choices. American Behavioral Scientist, 31, 327-340.

43. Zillmann, D., \& Bryant, J. (eds). (1985). Selective exposure to communication. Hillsdale, NJ: Lawrence Erlbaum. 


\title{
KARAKTERISTIKE UPOTREBE INTERNETA KAO SREDSTVA PERCIPIRANE REDUKCIJE STRESA KOD STUDENATA MEDICINSKIH NAUKA
}

\author{
Darko Hinić*, Jelena Jović ${ }^{\prime *}$, Dragana Ignjatović Ristić ${ }^{* * *}$ \\ ${ }^{*}$ Univerzitet u Kragujevcu, Prirodno-matematički $i$ \\ Filološko-umetnički fakultet

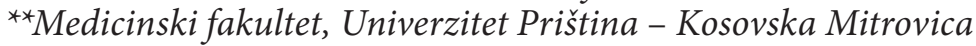 \\ ${ }^{* *}$ Univerzitet u Kragujevcu, Fakultet medicinskih nauka
}

\begin{abstract}
Rezime
U najvećem broju studija o upotrebi medija navodi se da ljudi uglavnom koriste medije radi zadovoljenja instrumentalnih, emocionalnih i socijalnih potreba. Cilj ovog istraživanja bio je da se identifikuju specifične karakteristike upotrebe interneta u populaciji studenata medicinskih nauka koji koriste internet kao sredstvo za redukciju stresa.

Uzorak je činio 231 student (34\% muškog i 66\% ženskog pola), prosečne starosti $A S=22,44 ; S D=2,090$. Ispitanici su svrstani u dve grupe na osnovu toga da li svesno koriste internet za ublažavanje posledica stresnih doživljaja ili ne.

Nalazi pokazuju da osobe koje navode internet kao sredstvo redukcije stresa provode značajno više vremena onlajn od ostalih korisnika interneta, češće prate sadržaje vezane za zabavu, kulturu i seks, a takođe, više koriste socijalne aplikacije i socijalne mreže. Za razliku od ostalih, ovi ispitanici se češće odlučuju za upoznavanje novih ljudi i potencijalnih partnera preko interneta, provode više vremena na profilima prijatelja, a više koriste i različite zabavne aplikacije, najčešće igrice.

Internet može imati značajnu ulogu u redukciji negativnih reakcija na stresne događaje, tako da sajberprostor možemo posmatrati kao pogodno tlo za veću aktivnost edukativnih, preventivnih i savetodavnih službi.

Glavno ograničenje ove studije je specifičnost uzorka (samo studenti medicinskih nauka). U narednim studijama nivo stresa bi trebalo i formalno meriti.
\end{abstract}

Ključne reči: internet upotreba, studenti medicinskih nauka, teorija upravljanja raspoloženjem, stres, teorija upotrebe i gratifikacije

Primljeno: 18.06.2016.

Prihvaćeno: 21.09.2016. 